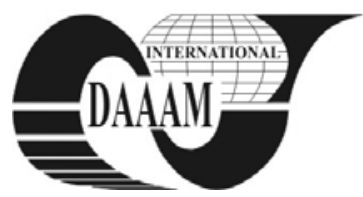

Annals of DAAAM for 2011 \& Proceedings of the 22nd International DAAAM Symposium, Volume 22, No. 1, ISSN 1726-9679 ISBN 978-3-901509-83-4, Editor B. Katalinic, Published by DAAAM International, Vienna, Austria, EU, 2011 Make Harmony between Technology and Nature, and Your Mind will Fly Free as a Bird Annals \& Proceedings of DAAAM International 2011

\title{
EXPORT CREDIT INSURANCE, ANOTHER FORM OF STATE AID?
}

\author{
ROSU, A[ngelica]; GAVRILA, S[imona] \& CRISTEA, S[ilvia] L[ucia]
}

\begin{abstract}
Starting from both competition policy, which is a major point of interest for each state and for the international community as a whole, as well as from the attention paid by the competition regulators, it has developed a true competition law. Studying national and international regulations in the field, the present work aims to be an incursion, signaling through the observation method and the comparative aspects between measures of aid and export credit, as well as the constraints that may arise in their existence.
\end{abstract}

Key words: competition, credit, export, insurance, guarantees

\section{INTRODUCTION}

The purpose of competition law is to protect economic competition, but competition policy as a whole, has not only economic but also social and political purposes. It concerns not only the promotion of efficient production, but also seeks to achieve economic policies to promote growth, raise living standards and close approximation between the states (Blasselle, R., 2005).

To the need to protect the economy against anticompetitive practices it was questioned whether export credit insurance, charged the state directly or through a legal entity of private law firms, is no more a form of aid or subsidy than real insurance. This is the provoking question underlying the present study.

The state's support responds to the need to facilitate foreign trade, in order to stimulate domestic industry affected by unemployment, or, at a more general level, in order to improve the balance of accounts and facilitate entry into new markets. Without doubt, however, the export credit insurance strengthens the position of the recipient (Gavrilă, S., 2008).

\section{MEASURES OF AID AND EXPORT CREDIT INSURANCE}

At international level, state aids are forbidden because they involve discriminatory measures that favor domestic activities. By this they tend to replace customs barriers were removed and also to remove the equality of means (Roşu, A., 2010).

The fundamental difference that is established between support measures and export credit insurance refers to the fact that the insurer state accepts the credit risk only in return for genuine consideration, which is the premium. This premium is not just a nominal amount meant to cover only the costs of administration; it is calculated according to the hedged risk. Calculating probabilities is impractical to cover risks in foreign trade, but the authorized bodies try to ensure the financial equilibrium of their operations and, in this view, they claim to policyholders premiums that are a serious equivalent. The state aid subsists in order to save the financial insurer body in case of necessity, but this is, in principle, self suporting. Thus, the insurer body is managing its risks trying not only to cover sinister of premium funds, but also to make reservations for the future.

The Decision issued by the Organisation for Economic Co-operation and Development (OECD) Council in 1959 confirmed this criterion of distinction. Export credit insurance is included in a list of export support measures, but only if the premium long term's value is not considered clearly enough to cover costs and damages suffered by the insurer body.

The main restrictions were imposed in respect of export credit insurance by the OECD and the European Union, for which in the present study we will follow these two directions.

\section{OECD REGULATIONS}

On the occasion of summits in Rambouillet (1975) and Porto Franco (1976), the main exporting countries have established the need to avoid excessive overbid on public aid offered to exporters and thus appeared the first regulations relating to export credits. After difficult negotiations, seven exporting countries (the former West Germany, Canada, USA, France, Italy, Japan and the United Kingdom), without concluding a treaty itself, have decided that from 1976 to pursue national policies converge on loans export, thus accepting their alignment.

Under the aegis of the OECD Trade Committee another states, this time no-member states (Austria, Australia, EEC, Finland, Norway, New Zealand, Sweden, Switzerland) have progressively joined to this first "Consensus" as it was called, which otherwise was amended and supplemented by a more formal arrangement which came into existence in 1978.

The main purpose of the Arrangement is to provide a framework for the orderly use of officially supported export credits. In practice, this means providing for a level playing field (whereby exporters compete on the basis of the price and quality of their products rather than the financial terms provided) and working to eliminate trade distortions related to officially supported export credits. There are also restrictions on the provision of tied aid.

It is worth noting that the OECD Arrangement on guidelines for officially supported export credits was adopted by the Council trough the Decision 93/112/EEC (1993), gaining power as rule of law, with its need to comply in the European Union.

In 1998, new disciplines on minimum risk premium were integrated into the Arrangement. These disciplines, known as the Knaepen Package, came into force on 1 April 1999, following over four years of intensive work by the Participants' Working Group of Experts on Premia and Related Conditions from the time that the Participants agreed a Declaration of Principle and Mandate for the Group's work in September 1994. This clearly indicates that it addresses to insurers, 
guarantors or sponsors in order to achieve alignment of prices given by the so-called traditional "related conditions".

\section{PRINCIPLES RELATING TO INSURANCE PREMIUMS}

Among the guiding principles relating to insurance against risk premiums imposed on the country, we can mention: their calculation taking into account the risk; elimination of distortions of competition and leveling conditions take into account the difference in quality of products offered; the premiums should not be insufficient to cover administrative expenses and long-term losses; the conditions determining the premiums are transparent to the export credit institutions participating in the Consensus states; the premiums concern medium to long term loans with a repayment period of two years and over (exclusive of agricultural products and military sales).

By establishing the minimum premiums (Benchmarks) it increases the possibility of concluding agreements for coinsurance and reinsurance. In some cases, which are specifically provided, it is possible that the insurance premiums drop below the minimum, but only if credit insurance is against country risk.

The EU legislation paid particular attention to how the insurance premium down, setting the following principles: the premium should correspond to the risk for which insurance was made (country risk, sovereign, public or private); the premium must reflect the amount and conditions guaranteed loans; the premium should not be set at a level insufficient to cover the costs incurred on long-term management. In determining the amount of premium, the insurer will consider the insured share, the assessment of country risk, the creditworthiness and the total risk.

The cases in which the export credit insurance will be cheaper, are extraordinary and refers to the existence of situations where the loan comes with certain guarantees: unconditional security emanating from a third country; existence of an seized account opened outside the buyer or borrower state; establishment of a security interest on shares or debentures outside the purchaser or borrower State; establishment of a mortgage on properties located abroad; insurance or guarantee provided by a third State; existence of an agreed debtor, acknowledged as being less risky than the National Bank or correspondent Ministry of Finance; cofinancing with international financial institutions; currency financing, in which case there is no risk in foreign exchange.

OECD Expert Group Methodology uses three factors established by precise equations: economic situation, financial situation and past experiences with regard to payments. The fourth factor, which concerns the political context, making calls is not fixed to the equation.

\section{EU REGULATIONS ON EXPORT CREDIT INSURANCE}

The most important internal legislation on export credits in the EU is the Directive 98/29/EC on harmonisation of the main provisions concerning export credit insurance for transactions with medium and long-term cover (1998). In its preamble it was underlined the fundamental role that export credit insurance plays in international trade, the essential instrument of trade policy and the fact that the differences between public systems of export credit insurance can cause the distortions in competition between enterprises (Cristea S.,2009).
According to these regulations, the term "supplier credit" applies to a commercial contract providing for an export of goods and/or services done by one or more suppliers and one or more buyers, whereby the buyer(s) undertake to pay the supplier(s) on cash terms or on credit terms.

This act replaced Council Directive 70/509/EEC of 27 October 1970 on the adoption of a common credit insurance policy for medium- and long-term transactions with public buyers and Council Directive 70/510/EEC of 27 October 1970 on the adoption of a common credit insurance policy for medium and long-term transactions with private buyers.

In the field of short-term export credit insurance it is important to mention the Communication of the Commission to the Member States pursuant to Article 93 (1) of the EC Treaty applying Articles 92 and 93 of the Treaty to short-term exportcredit insurance (1997). As stated in its introduction, the purpose of this Communication is to remove such distortions due to State aid in that sector of the export-credit insurance business in which there is competition between public or publicly supported export-credit insurers and private exportcredit insurers.

\section{CONCLUSIONS}

Whereas export credit is of primary importance in international trade and there are important differences between official credit insurance systems it was necessary the intervention of international bodies. Aware that greater legal certainty and transparency is important both for business and for states, OCDE and European Union started negociation in view of harmonising the different rules on export credit insurance. According to the EU rules on State aid, the public export credit agencies cannot insure risks that private insurance companies are able to cover in a normal market situation. In December 2008, as a consequence of the financial crisis, the European Commission has granted to the specialized bodies a temporary permission to guarantee export transactions in EU Member States when the payment term is under two years. The permission is valid until 31 December 2011.

\section{REFERENCES}

Blasselle, R., (2005), Traite de droit europeen de la concurrence. Tome II B, Editions Publisud, ISBN: 286600-999-1, Paris

Communication of the Commission to the Member States pursuant to Article 93 (1) of the EC Treaty applying Articles 92 and 93 of the Treaty to short-term exportcredit insurance (published in Official Journal C 281, 17/09/1997 P. $0004-0010)$

Cristea, S., (2009), Tehnici de finanţare în dreptul afacerilor, Editura ASE, ISBN 978-606-505-200-0, Bucureşti

Decision 93/112/EEC, published in Official Journal L 44, 22/2/1993, p.1, amended by Decision 97/530/CE (JO L 216, 8.8.1997, p. 77)

Directive 98/29/EC of 7 May 1998 on harmonisation of the main provisions concerning export credit insurance for transactions with medium and long-term cover (published in Official Journal L 148, 19/05/1998 P. 0022 - 0032)

Gavrilă, S., P., (2008), Contractul de asigurare a creditelor pentru export, Editura Hamangiu, ISBN: 978-973-183642-3, Bucureşti

Roşu, A., (2010), Dreptul concurenţei în Uniunea Europeană. Curs universitar, Editura Pro Universitaria, ISBN 978973-129-615-9, Bucureşti 